九州大学学術情報リポジトリ

Kyushu University Institutional Repository

\title{
Experimental Study on Carbon Based Adsorbents for Greenhouse Dehumidification
}

Sultan, Muhammad

Interdisciplinary Graduate School of Engineering Sciences, Kyushu University I International Institute for Carbon-Neutral Energy Research (WPI-I2CNER), Kyushu University

El-Sharkaw, Ibrahim I

Faculty of Engineering Sciences, Kyushu University | Mechanical Power Engineering Department, Faculty of Engineering, Mansoura University | International Institute for Carbon-Neutral

Energy Research (WPI-I2CNER), Kyushu University

Miyazaki, Takahiko

Faculty of Engineering Sciences, Kyushu University | International Institute for CarbonNeutral Energy Research (WPI-I2CNER), Kyushu University

Saha, Bidyut Baran

Interdisciplinary Graduate School of Engineering Sciences, Kyushu University | International Institute for Carbon-Neutral Energy Research (WPI-I2CNER), Kyushu University

他

https://doi.org/10.5109/1495157

出版情報 : Evergreen. 1 (2)，pp.5-11，2014-09. Green Asia Education Center バージョン：

権利関係 : 


\title{
Experimental Study on Carbon Based Adsorbents for Greenhouse Dehumidification
}

\author{
Muhammad Sultan ${ }^{1,4}$, Ibrahim I. El-Sharkawy ${ }^{2,3,4}$, Takahiko Miyazaki ${ }^{2,4^{*}}$ \\ Bidyut Baran Saha ${ }^{1,4}$, Shigeru Koyama ${ }^{2,4}$ \\ ${ }^{1}$ Interdisciplinary Graduate School of Engineering Sciences, Kyushu University, \\ 6-1Kasuga-koen, Kasuga-shi, Fukuoka 816-8580, Japan \\ ${ }^{2}$ Faculty of Engineering Sciences, Kyushu University, 6-1Kasuga-koen, Kasuga-shi, \\ Fukuoka 816-8580, Japan \\ ${ }^{3}$ Mechanical Power Engineering Department, Faculty of Engineering, Mansoura University, \\ El-Mansoura, Egypt \\ ${ }^{4}$ International Institute for Carbon-Neutral Energy Research (WPI-I2CNER), Kyushu University, \\ 744 Motooka, Fukuoka 819-039, Japan
}

*Author to whom correspondence should be addressed, Email: miyazaki.takahiko.735@m.kyushu-u.ac.jp

(Received June 18, 2014; accepted August 15, 2014)

\begin{abstract}
Adsorption of water vapors onto silica-gel and two types of carbon based adsorbents (CBAs) has been experimentally investigated. Adsorption data has been analyzed for various adsorption models. The Guggenhein, Anderson, De-Boer (GAB) and Dubinin-Astakhov (D-A) models gave the good fit for silica-gel and CBAs respectively with an error of less than $5 \%$. The greenhouse air-conditioning is proposed the water sorption application for CBAs. Results showed that the CBAs can dehumidify the greenhouse air by utilizing low regeneration temperature and 3-6 times less adsorbent mass as compared to silica-gel. The isosteric heat of adsorption of CBAs/water pair does not extremely effect on dehumidification performance.
\end{abstract}

Keywords: activated carbon, water, greenhouse, dehumidification, air-conditioning

\section{Introduction}

Photosynthesis and Evapo-transpiration are the basic phenomena for plants growth by which water vapors are released into the air that increases the humidity in the greenhouse continuously. The required relative humidity $(\mathrm{RH})$ for a plant depends on its ideal vapor pressure deficit (VPD) which varies depending upon the product growth stage, its maturity, danger of insect/pest/fungus attack, extreme weather conditions, and water stresses etc. A low cost dehumidification and air-conditioning (AC) system is always required in greenhouse to ensure maximum product yield. Desiccant air-conditioning (DAC) systems are getting lot of attention for room AC application. In the present study the activated carbons are analyzed for greenhouse AC application.

The carbon based adsorbents (CBAs) are usually considered as hydrophobic substance but many studies have shown their water adsorbing ability ${ }^{1-4)}$. The adsorption performance of CBAs is entirely different at different adsorption temperatures and relative pressures $\left(\mathrm{P} / \mathrm{P}_{\mathrm{o}}\right)$ or $\mathrm{RH}$ which is based on source of CBAs, activation temperature, and the employed techniques ${ }^{5}$. As compared to conventional silica-gel, many materials gave interesting water sorption performance under certain conditions e.g. activated carbon $^{5)}$, titanium dioxide $^{6)}$, and composite desiccants ${ }^{7,8)}$ for adsorption uptake; whereas coconut coir ${ }^{9}$ for adsorption kinetics. Most of the CBAs adsorb very small amount of water vapors at lower $\mathrm{P} / \mathrm{P}_{\mathrm{o}}$ but at certain upper range of $\mathrm{P} / \mathrm{P}_{\mathrm{o}}$ it adsorb its maximum amount ${ }^{10)}$. Due to this ability the present study focus on the use of CBAs for greenhouse AC. The ideal VPD for most of the greenhouse products varies from 0.45 to $1.25 \mathrm{kPa}^{11)}$ which means CBAs can be interesting candidates for greenhouse dehumidification.

In the present study an investigation is made on CBAs/water pair for greenhouse AC application. The experimental data of water vapor adsorption onto silica-gel and two types of CBAs have been correlated 


\section{Nomenclature}

$\begin{array}{ll}\text { AC } & \text { air-conditioning } \\ \text { ACP } & \text { activated carbon powder } \\ \text { ACF } & \text { activated carbon fiber } \\ \text { BET } & \text { Brunauer-Emmett-Teller model } \\ \text { CBAs } & \text { carbon based adsorbents } \\ \text { DAC } & \text { desiccant air-conditioning } \\ \text { D-A } & \text { Dubinin-Astakhov model }\end{array}$

$\delta \mathrm{D}_{1}-\delta \mathrm{D}_{4} \quad$ uncertainties in experimental parameters

E adsorption characteristic parameter $[\mathrm{kJ} / \mathrm{kg}]$

$\mathrm{E}(\%) \quad$ relative percentage deviation module

GAB Guggenhein, Anderson, De-Boer model

$\mathrm{MF}_{\mathrm{A}-\mathrm{A}}$ adsorbent-to-air mass fraction [ $\mathrm{g}_{\mathrm{ads}} / \mathrm{kg}_{\mathrm{DA}}$ ]

n fitting parameter [-]

$\mathrm{P} \quad$ pressure $[\mathrm{kPa}]$

$\mathrm{P}_{\mathrm{o}} \quad$ saturation pressure $[\mathrm{kPa}]$

$\mathrm{P} / \mathrm{P}_{\mathrm{o}} \quad$ relative pressure [-]

Q Heating energy [kW]

Q $\quad$ isosteric heat of sorption $[\mathrm{kJ} / \mathrm{kg}]$

$\mathrm{R} \quad$ specific gas constant for water $[\mathrm{kJ} / \mathrm{kg}-\mathrm{K}]$

$\mathrm{T}$ temperature $[\mathrm{K}]$

$\delta \mathrm{U} \quad$ uncertainty in experimental data

$\mu_{1-} \mu_{4} \quad$ adjustable fittings parameters

VPD vapor pressure deficit $[\mathrm{kPa}]$

W humidity ratio $\left[\mathrm{g}_{\mathrm{H} 2 \mathrm{O}} / \mathrm{kg}_{\mathrm{DA}}\right]$

$\mathrm{X} \quad$ equilibrium adsorption uptake $[\mathrm{kg} / \mathrm{kg}]$

$\mathrm{X}_{\mathrm{o}} \quad$ maximum adsorption capacity $[\mathrm{kg} / \mathrm{kg}]$

$\emptyset^{*} \quad$ slope of dehumidification line [-]

$\varnothing \quad$ slope of enthalpy line [-]

$\Delta \quad$ heat of condensation of water $[\mathrm{kJ} / \mathrm{kg}]$

using various adsorption models. The isosteric heat of adsorption $\left(\mathrm{Q}_{\mathrm{st}}\right)$ and adsorbent-air mass fraction $\left(\mathrm{MF}_{\mathrm{A}-\mathrm{A}}\right)$ has also been extracted. Psychometric comparison between CBAs and silica-gel is given in relation with regeneration temperature which highlights the importance of carbon/water pair in adsorption science.

\section{Experiments}

\subsection{Description of the experimental setup}

An experimental setup had been employed to obtain the water vapor adsorption isotherms for $\mathrm{RD}$ type silica-gel (Fuji Silysia Chemical Ltd. Japan) and two types of CBAs namely (i) activated carbon powder

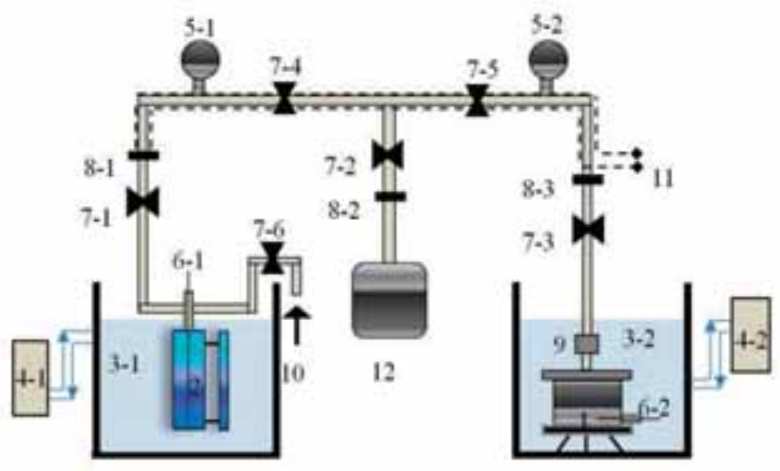

(1) adsorber, (2) evaporator/condenser, (3-1 to 3-2) constant temperature water baths, (4-1 to 4-2) water circulators, (5-1 to 5-2) pressure gauges, (6-1 to 6-2) thermocouples, (7-1 to 7-6) valves, (8-1 to 8-3) flange connections, (9) filter, (10) adsorbate suction, (11) tape heater with controller, (12) vacuum pump

Fig. 1 Schematic diagram of the experimental setup.

Table 1 Physical properties of the adsorbents.

\begin{tabular}{lccc}
\hline $\begin{array}{l}\text { Adsorbents/ } \\
\text { properties }\end{array}$ & $\begin{array}{c}\text { ACP } \\
(\text { Maxsorb- } \\
\text { III })^{12)}\end{array}$ & $\begin{array}{c}\text { ACF } \\
(\mathrm{A}-20)^{13)}\end{array}$ & $\begin{array}{c}\text { Silica-gel } \\
\left.(\mathrm{RD})^{14}\right)\end{array}$ \\
\hline $\begin{array}{l}\text { Surface area } \\
\left(\mathrm{m}^{2} / \mathrm{kg}\right)\end{array}$ & $3.045 \times 10^{6}$ & $1.95 \times 10^{6}$ & $6.50 \times 10^{5}$ \\
$\begin{array}{l}\text { Micropores } \\
\text { volume } \\
\left(\mathrm{m}^{3} / \mathrm{kg}\right)\end{array}$ & $1.7 \times 10^{-3}$ & $\begin{array}{c}1.028 \times \\
10^{-3}\end{array}$ & $3.5 \times 10^{-4}$ \\
$\begin{array}{l}\text { Avg. pore } \\
\text { diameter }(\mathrm{m})\end{array}$ & $1.12 \times 10^{-9}$ & $2.16 \times 10^{-9}$ & $2.1 \times 10^{-9}$ \\
\hline
\end{tabular}

(ACP) of type Maxsorb-III, and (ii) activated carbon fiber (ACF) of type A-20. The surface area, micropore volume and pore diameter of the adsorbents are given in Table $1^{12-14)}$. The schematic of the experimental apparatus is shown in Fig. 1. The apparatus was mainly consists of an adsorber, an evaporator/condenser, temperature control units, pressure and temperature sensors, filter, tape heater, vacuum pump, data logger, and a digital camera. The AND-MC-1000 digital balance with an accuracy of $\pm 0.01 \mathrm{~g}$ was used to measure the sample weight. The evaporator was employing two tubes; smaller one for recording the data $(d=4.8 \mathrm{~mm} \pm$ $0.5 \mathrm{~mm}$ ) followed by the bigger one to provide the adsorbate reservoir $(\mathrm{d}=20 \mathrm{~mm} \pm 0.7 \mathrm{~mm})$. The design of evaporator facilitated the measurement at relatively lower vapor pressure range when adsorption amount was very small. The evaporator could keep more than 40 grams of water which was sufficient for one go. The cylindrical shape adsorber with $\mathrm{d}=110.3 \mathrm{~mm}$, and $\mathrm{h}=100 \mathrm{~mm}$ gave enough space for adsorption as well as for loading/unloading the sample. A filter was used with 
adsorber to avoid the flying of the sample particles during the evacuation. The measuring range of KL79 type pressure gauges was $0-20 \mathrm{kPa}$ with an accuracy of $\pm 0.3 \% \mathrm{~F}$.S. The accuracies of $\mathrm{K}$ type thermocouples and temperature control units were $\pm 0.05^{\circ} \mathrm{C}$ and $\pm 0.1^{\circ} \mathrm{C}$ respectively. Vacuum pump was capable to provide the vacuum up to $1.0 \mathrm{~Pa}$. As the experiments were made in winter conditions so an adjustable voltage tape heater was used for temperature adjustment onto the tubing to avoid the condensation. A high resolution camera with stand had been mounted to record the water readings in the evaporator. The minimum measurable change in evaporator's height was $0.25 \mathrm{~mm}$ which is almost $1.25 \%$ of the total uptake. The accuracy in height measurement was $\pm 0.25 \mathrm{~mm}$. The uncertainty in the experimental data was estimated by Eq. 1 which equals to $\pm 0.045 \mathrm{~kg} / \mathrm{kg}$.

$$
\delta U=\sqrt{\left(\frac{\partial U}{\partial D_{1}} \delta D_{1}\right)^{2}+\left(\frac{\partial U}{\partial D_{2}} \delta D_{2}\right)^{2}+\left(\frac{\partial U}{\partial D_{3}} \delta D_{3}\right)^{2}+\left(\frac{\partial U}{\partial D_{4}} \delta D_{4}\right)^{2}}
$$

Where $\delta U$ is the uncertainty in measuring the adsorption uptake $[\mathrm{kg} / \mathrm{kg}]$, and $\delta \mathrm{D}_{1}-\delta \mathrm{D}_{4}$ are the uncertainties in measuring each experimental parameter.

\subsection{Experimental procedure}

Initially adsorbents were dried in an oven at $120^{\circ} \mathrm{C}$ for 6-8 hours. Nearly $8-10 \mathrm{~g}$ oven-dried samples were used for water adsorption isotherms. With the adjustment of valves (7-1 to 7-6 in Fig. 1), whole system was evacuated part by part by using the vacuum pump. The pressure readings were observed continuously after evacuation to make sure there was no leakage from the system. Once the system became ready, sufficient amount of distilled water was added into the evaporator from adsorbate suction (no.10 at Fig. 1) and meanwhile oven-dried sample was loaded into the adsorber. During the sample loading into adsorber the ACP particles might fly because of its low density; which was avoided carefully. The mass of the ACP particles attached with the loading-pan after finishing loading into adsorber was subtracted from the total mass. The whole system was evacuated once again part by part for $1 \mathrm{~Pa}$ in adsorber side and up to corresponding vapor pressure of water in evaporator side. Before starting the adsorption the sample had been regenerated and evacuated at $85^{\circ} \mathrm{C}$ for 4-5 hours. Now the adsorber had fixed on the required adsorption temperature whereas the evaporator's temperature was varied from $2{ }^{\circ} \mathrm{C}$ to adsorption/adsorber temperature by keeping $\mathrm{P} / \mathrm{P}_{\mathrm{o}}=0.90$ at maximum. Once the temperature in adsorber and evaporator became steady, the valves (except 7-2 and 7-6) were opened for adsorption. The voltage of tape heater was adjusted in such a way that the temperature onto the tube always remained considerably higher than the evaporator temperature (roughly $5-10^{\circ} \mathrm{C}$ ) which ensured zero condensation. The evaporator scale had been observed and recorded continuously by the high resolution digital camera to measure the uptake of water vapors onto the

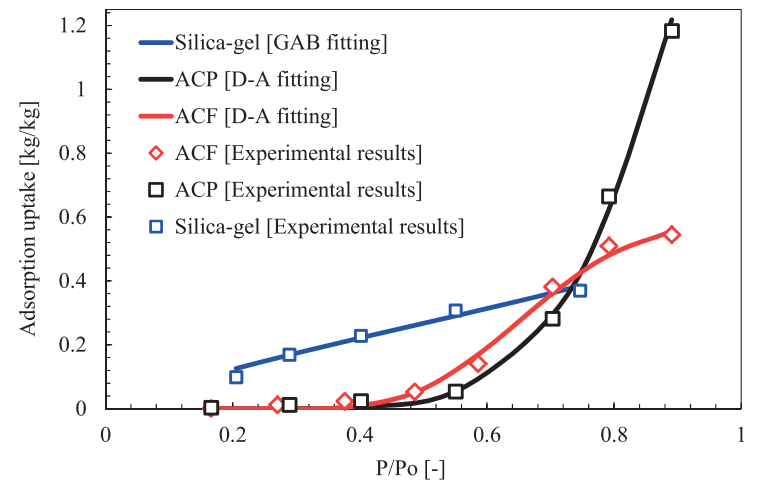

Fig. 2 Water vapor adsorption isotherm for (i) silica-gel, (ii) activated carbon powder (ACP), and (iii) activated carbon fiber (ACF) at $30^{\circ} \mathrm{C}$.

adsorbent. Once the adsorption equilibrium obtained, the evaporator temperature was increased to the next point reading. By increasing the evaporator's temperature, the vapor pressure of water increased which endorsed further adsorption. In the present experiments the maximum evaporator temperature was corresponds to relative pressure less than $90 \%$ to avoid desorption. During the calculation for adsorption isotherm, the mass of water vapor at certain conditions that remains in the tube and adsorber itself was also subtracted.

\section{Results and discussion}

\subsection{Adsorption equilibrium and heat of adsorption}

Water vapor adsorption isotherms for silica-gel and two types of CBAs namely (i) activated carbon powder (ACP), and (ii) activated carbon fiber (ACF) are measured experimentally at adsorption temperature of $30^{\circ} \mathrm{C}$. The experimental results are shown in Fig. 2. The adsorption isotherms trend of CBAs clarifies their water adsorption ability at higher $\mathrm{P} / \mathrm{P}_{\mathrm{o}}$. Similar kind of trend for carbon/water pairs are also reported by many researchers ${ }^{2)-3), 10)}$. Pore width of CBAs might be the reason of this kind of behavior and the same trend can be shifted towards lower $\mathrm{P} / \mathrm{P}_{\mathrm{o}}$ by reducing pore width ${ }^{15)}$. Brunauer-Emmett-Teller (BET) adsorption model (Eq. 1) is commonly used for water adsorption data but it is only reliable for $\mathrm{P} / \mathrm{P}_{0}<0.45$. The Guggenhein, Anderson, De-Boer (GAB) adsorption model (Eq. 2) is considered reliable for higher relative pressure $\left(\mathrm{P} / \mathrm{P}_{0}=0.10-0.90\right)$ and it was found suitable to represent experimental data of silica-gel as shown in Fig. 2. The following adsorption models (Eq. 2-6) including GAB model were tried to fit the experimental data of CBAs but reliable fitting could not obtained.

\section{BET model ${ }^{16)}$}

$$
X=\frac{\left[\mu_{1} \mu_{2}\left(P / P_{o}\right)\right]}{\left[( 1 - ( P / P _ { o } ) ] \left[\left(1-\left(P / P_{o}\right)+\mu_{2}\left(P / P_{o}\right)\right]\right.\right.}
$$


2. GAB model ${ }^{17)}$

$X=\frac{\left[\mu_{1} \mu_{2} \mu_{3}\left(P / P_{o}\right)\right]}{\left[\left(1-\mu_{2}\left(P / P_{o}\right)\right]\left[\left(1-\mu_{2}\left(P / P_{o}\right)+\mu_{2} \mu_{3}\left(P / P_{o}\right)\right]\right.\right.}$

3. Oswin $\operatorname{model}^{18)}$

$$
X=\mu_{1}\left[\frac{\left(P / P_{o}\right)}{1-\left(P / P_{o}\right)}\right]^{\mu_{2}}
$$

4. Freundlich model ${ }^{19)}$

$X=\mu_{1}\left[\frac{P}{P_{o}}\right]^{\left(1 / \mu_{2}\right)}$

5. Peleg model $^{17)}$

$X=\mu_{1}\left[\frac{P}{P_{o}}\right]^{\mu_{3}}+\mu_{2}\left[\frac{P}{P_{o}}\right]^{\mu_{4}}$

Where $\mathrm{X}$ is the adsorption uptake of water $[\mathrm{kg} / \mathrm{kg}] ; \mu_{1}$, $\mu_{2}, \mu_{3}, \mu_{4}$ are the model constants; and $\mathrm{P} / \mathrm{P}_{\mathrm{o}}$ represents the relative pressure.

The following Dubinin-Astakhov (D-A) model (Eq. 7-8) gives good fit with the experimental data of ACP and $\mathrm{ACF}$ for $\mathrm{P} / \mathrm{P}_{\mathrm{o}}$ range of $0.50-0.90$ and $0.45-0.90$ respectively. The goodness of the fit can be visualized from the Fig. 2. The D-A equation also represent the Dubinin-Radushkevich (D-R) equation for $\mathrm{n}=2$.

\section{D-A model ${ }^{20)}$}

$X=X_{o} \exp \left[-\left(\frac{A}{E}\right)^{n}\right]$

$A=R T_{a d s} \ln \left(\frac{P_{o}}{P}\right)$

Where, $\mathrm{X}=$ water vapor uptake $[\mathrm{kg} / \mathrm{kg}]$

$\mathrm{X}_{\mathrm{o}}=$ maximum uptake of water vapors $[\mathrm{kg} / \mathrm{kg}]$

$\mathrm{E}=$ adsorption characteristics energy $[\mathrm{kJ} / \mathrm{kg}]$

$\mathrm{n}=$ fitting parameter

$\mathrm{R}=$ specific gas constant for water $[\mathrm{kJ} / \mathrm{kg}-\mathrm{K}]$

$\mathrm{T}_{\mathrm{ads}}=$ adsorption temperature $[\mathrm{K}]$

$\mathrm{P}=$ vapor pressure of water (evaporator side)

$\mathrm{P}_{\mathrm{o}}=$ saturation pressure (corresponding to $\mathrm{T}_{\mathrm{ads}}$ )

The estimated parameters of adsorption models for each adsorbent are given in Table 2. The fitting parameters are obtained through the linearization and non-linearization techniques by reducing mean relative percentage deviation module (E \%) which can be defined as:

$E(\%)=\frac{100}{N} \sum_{i=1}^{N}\left[\frac{\left|X_{\text {exp }}-X_{\text {cal }}\right|}{X_{\exp }}\right]$

Using D-A adsorption model with calculated fitting parameters, the isosteric heat of adsorption $\left(\mathrm{Q}_{\mathrm{st}}\right)$ is determined for ACP by the Clausius-Clapeyron relationship for certain uptake ${ }^{21)}$.

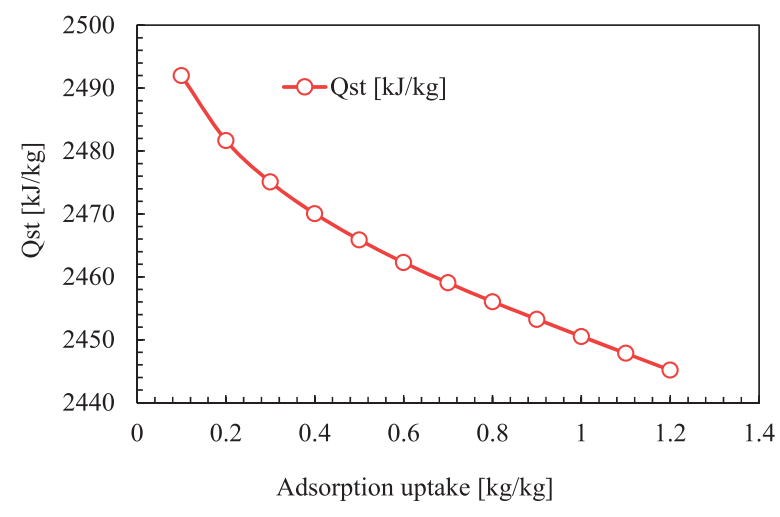

Fig. 3 Isosteric heat of adsorption for $\mathrm{ACP}$ as a function of adsorption uptake.

$\frac{Q_{s t}}{R}=-\left[\frac{\partial \ln P}{\partial\left(1 / T_{a d s}\right)}\right]_{X}$

It can be notices from the Fig. 3 that the isosteric heat of adsorption decreases with the increase in total uptake. It remains in the range of 2440 to $2500 \mathrm{~kJ} / \mathrm{kg}$ which is quite reasonable for dehumidification application in greenhouse.

\subsection{Psychometric analysis}

An appropriate growth region for a certain greenhouse product $^{11)}$ is shown by a black lined parallelogram in Fig. 4. If the greenhouse condition sits at point 1 (usual conditions of greenhouse), the ACP can be used for DAC by following the process-air lines 1-2 (dehumidification) and 2-3 (cooling). If the same air is considered for thermal regeneration, the regeneration-air lines can be plotted as (1-2'-3'). Most of the thermal loads at (2-3) and (1-2') are exchangeable via effective heat exchangers. The same system can be tracked for the silica-gel which will follow the process-air lines (1-4-5) and regeneration-air lines (1-4`-5') under same conditions. As the point 2 and 4 is dependent on adsorption heat of corresponding adsorbent, the slope of the dehumidification lines can be calculated by the following relationship:

$\emptyset^{*}=\frac{\Delta}{Q_{s t}} \emptyset$

Where, $\emptyset^{*}=$ slope of dehumidification line (1-2 and 1-4) $\varnothing=$ slope of enthalpy line on psychometric chart $\Delta=$ heat of condensation of water $[\mathrm{kJ} / \mathrm{kg}]$ $\mathrm{Q}_{\mathrm{st}}=$ isosteric heat of adsorption $[\mathrm{kJ} / \mathrm{kg}]$

The $\mathrm{Q}_{\mathrm{st}}$ for ACP goes nearly $2500 \mathrm{~kJ} / \mathrm{kg}$ at maximum, which means $\emptyset^{*} \cong 0.9 \emptyset$ so the ACP can track the ideal dehumidification process by following the isenthalpic process line. It means the thermodynamic dehumidification by ACP will not be so different from the silica-gel. For simple representation on psychometric 
Table 2 Estimated parameters of adsorption models for each adsorbent.

\begin{tabular}{|c|c|c|c|c|}
\hline Adsorption model & Parameters & Silica-gel & $\mathrm{ACP}$ & $\mathrm{ACF}$ \\
\hline \multirow{5}{*}{$\begin{array}{l}\text { Brunauer-Emmett- } \\
\text { Teller (BET) model }\end{array}$} & $\mathrm{P} / \mathrm{P}_{\mathrm{o}}$ range & $0.20-0.75$ & $0.20-0.80$ & $0.25-0.90$ \\
\hline & $\mu_{1}[\mathrm{~kg} / \mathrm{kg}]$ & 0.1054 & -0.1294 & 0.47 \\
\hline & $\mu_{2}[-]$ & -30.488 & -0.1267 & 0.0586 \\
\hline & $\mathrm{R}^{2}$ & 0.836 & 0.88 & 0.65 \\
\hline & E $(\%)$ & 22.65 & 17.45 & 42.49 \\
\hline \multirow{5}{*}{$\begin{array}{l}\text { Guggenhein, } \\
\text { Anderson, De-Boer } \\
\text { (GAB) model }\end{array}$} & $\mathrm{P} / \mathrm{P}_{\mathrm{o}}$ range & $0.20-0.75$ & $0.20-0.90$ & $0.25-0.90$ \\
\hline & $\mu_{1}[\mathrm{~kg} / \mathrm{kg}]$ & 0.361 & 2884.42 & 1.671 \\
\hline & $\mu_{2}[-]$ & 0.46 & $8.07 \mathrm{E}-6$ & 0.046 \\
\hline & $\mu_{3}[-]$ & 4.4343 & 0.9812 & 0.883 \\
\hline & $\mathrm{E}(\%)$ & 4.42 & 25.87 & 75.69 \\
\hline \multirow{5}{*}{ Oswin model } & $\mathrm{P} / \mathrm{P}_{\mathrm{o}}$ range & $0.20-0.75$ & $0.20-0.90$ & $0.15-0.90$ \\
\hline & $\mu_{1}[-]$ & 0.2447 & 0.050 & 0.0421 \\
\hline & $\mu_{2}[-]$ & 0.5209 & 1.6656 & 1.7761 \\
\hline & $\mathrm{R}^{2}$ & 0.90 & 0.986 & 0.883 \\
\hline & $\mathrm{E}(\%)$ & 14.59 & 20.55 & 87.78 \\
\hline \multirow{5}{*}{ Freundlich model } & $\mathrm{P} / \mathrm{P}_{\mathrm{o}}$ range & $0.20-0.75$ & $0.20-0.90$ & $0.15-0.90$ \\
\hline & $\mu_{1}[-]$ & 0.5404 & 0.999 & 1.193 \\
\hline & $\mu_{2}[-]$ & 0.9895 & 0.287 & 0.2502 \\
\hline & $\mathrm{R}^{2}$ & 0.971 & 0.937 & 0.98 \\
\hline & $\mathrm{E}(\%)$ & 7.64 & 48.09 & 23.69 \\
\hline \multirow{6}{*}{ Peleg model } & $\mathrm{P} / \mathrm{P}_{\mathrm{o}}$ range & $0.20-0.75$ & $0.20-0.90$ & $0.15-0.90$ \\
\hline & $\mu_{1}[-]$ & 0.5059 & 0.0612 & 0.895 \\
\hline & $\mu_{2}[-]$ & 0.02161 & 2.3233 & 0.493 \\
\hline & $\mu_{3}[-]$ & 0.8844 & 5.5195 & 4.333 \\
\hline & $\mu_{4}[-]$ & 58.7876 & 6.077 & 4.226 \\
\hline & E $(\%)$ & 7.33 & 39.99 & 20.27 \\
\hline \multirow{6}{*}{$\begin{array}{l}\text { Dubinin-Astakhov } \\
\text { (D-A) model }\end{array}$} & $\mathrm{P} / \mathrm{P}_{\mathrm{o}}$ range & $0.20-0.75$ & $0.50-0.90$ & $0.45-0.90$ \\
\hline & $X_{o}[\mathrm{~kg} / \mathrm{kg}]$ & 0.4244 & 2.02 & 0.576 \\
\hline & $\mathrm{E}[\mathrm{kJ} / \mathrm{kg}]$ & 184.202 & 28.57 & 68.484 \\
\hline & $\mathrm{n}[-]$ & 1.50 & 1.20 & 2.30 \\
\hline & $\mathrm{R}^{2}$ & 0.994 & 0.999 & 0.989 \\
\hline & E $(\%)$ & 5.21 & 3.48 & 4.95 \\
\hline
\end{tabular}

chart, the dehumidification lines (1-2 and 1-4) are plotted as isenthalpic lines. It looks that silica-gel is producing deep dehumidification but the mass flow rate for the silica-gel is lower as compared to ACP for same amount of adsorbent hence producing the same return air conditions (point 1). Fig. 4 shows that the ACP can be regenerated at lower regeneration temperature $\left(T_{1}\right)$ by employing higher regeneration-air humidity as compared to silica-gel which results in $\left(\mathrm{T}_{2}\right)$. It can be seen from Fig. 2 that the CBAs enabled 2-3 times higher moisture sorption ability at higher $\mathrm{P} / \mathrm{P}_{\mathrm{o}}$ or $\mathrm{RH}$ as compared to silica-gel. It means that ACP will give more dehumidification if the same amount of adsorbents is functioned at regeneration temperature $T_{1}$. Silica-gel can accommodate the adsorption deficiency by dehumidifying at lower $\mathrm{RH}$ but it will require a higher regeneration temperature $\left(\mathrm{T}_{2}\right)$. The adsorbent-to-air mass fraction $\left(\mathrm{MF}_{\mathrm{A}-\mathrm{A}}\right)$ for each adsorbent can be identified by the following relationship.

$\mathrm{MF}_{\mathrm{A}-\mathrm{A}}=\left(\frac{\Delta X}{\Delta W}\right)_{\Delta R H}=\left(\frac{X_{1}-X_{2}}{W_{2}-W_{1}}\right)_{\Delta R H}$

Where, $\mathrm{MF}_{\mathrm{A}-\mathrm{A}}=$ adsorbent-air mass fraction [ $\mathrm{g}_{\mathrm{ads}} / \mathrm{kg}_{\mathrm{DA}}$ ] $\mathrm{W}_{1}, \mathrm{~W}_{2}=$ adsorption uptakes $\left[\mathrm{g}_{\mathrm{H} 2 \mathrm{O}} / \mathrm{g}_{\mathrm{ads}}\right]$

$\mathrm{X}_{1}, \mathrm{X}_{2}=$ humidity ratios $\left[\mathrm{g}_{\mathrm{H} 2 \mathrm{O}} / \mathrm{kg}_{\mathrm{DA}}\right]$

The effect of regeneration temperature on $\mathrm{MF}_{\mathrm{A}-\mathrm{A}}$ is shown in Fig. 5. The $\mathrm{MF}_{\mathrm{A}-\mathrm{A}}$ and heating energy (Q) increases with the increase in regeneration temperature for each adsorbent. The $\mathrm{MF}_{\mathrm{A}-\mathrm{A}}$ for $\mathrm{ACP}$ is found quite low as compared to silica gel which ensures a promising system size. For certain air amount, the ACP can dehumidify the air by utilizing 3-6 times less adsorbent mass as compared to silica-gel. This ability starts decreasing with the increase in regeneration temperature. 


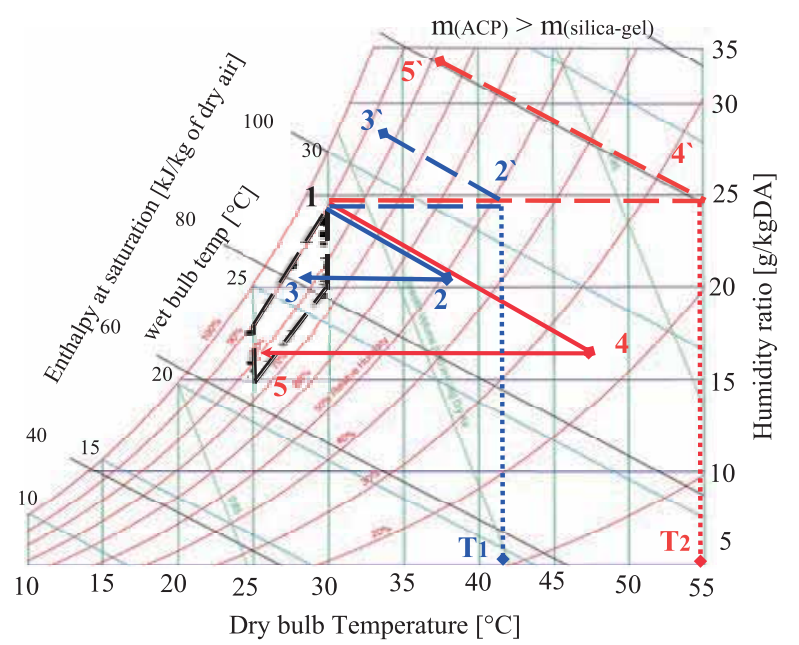

Fig. 4 Psychometric comparison of dehumidification by ACP and silica-gel for greenhouse air-conditioning.

It is clear that silica-gel can give deep dehumidification as compared to ACP but it is not essential in greenhouse. The pre-cooling of the ACP before dehumidification can also be used as an asset to obtain lower absolute humidity and dew point temperature. Due to this ability CBAs can be the potential candidates for coupling with evaporative cooling and hybrid DAC systems.

\section{Conclusion}

Adsorption of water vapors onto silica-gel and two types of carbon based adsorbents (CBAs) has been experimentally investigated for greenhouse air-conditioning (AC) application. The CBAs enabled 2-3 times higher water vapor adsorption amount as compared to silica-gel. The experimental data of water vapor adsorption is analyzed for various adsorption models. The Dubinin-Astakhov (D-A) and Guggenhein, Anderson, De-Boer (GAB) adsorption models gave the good fitting results for CBAs and silica-gel respectively with an error of less than $5 \%$. The CBAs dehumidify the greenhouse air by utilizing 3-6 times less adsorbent mass as compared to silica-gel and this ability starts decreasing with the increase in regeneration temperature. The lower adsorbent-air mass fractions of CBAs also ensure the optimum system size for greenhouse AC. The net isosteric heat of adsorption of CBAs does not extremely effect on dehumidification performance of CBAs. In comparison with silica-gel, the CBAs required relatively low regeneration temperature for greenhouse dehumidification which gives an opportunity to utilize low grade waste heat and renewable energy sources.

\section{References}

1) P. Kim and S. Agnihotri, J. Colloid Interface Sci., 325, 64 (2008).

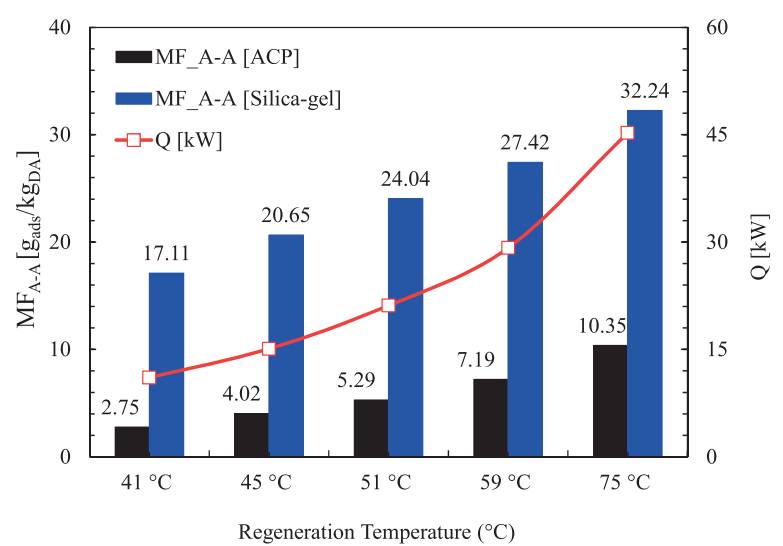

Fig. 5 Effect of regeneration temperature on adsorbent-air mass fraction $\left(\mathrm{MF}_{\mathrm{A}-\mathrm{A}}\right)$ for $\mathrm{ACP}$ and silica-gel.

2) D. D. Do and H. D. Do, Carbon, 38, 767 (2000).

3) S. Qi, K. J. Hay and M. J. Rood, J. Environ. Eng., 124, 1130 (1998).

4) C. Vagner, G. Finqueneisel, T. Zimny and J. Weber, Fuel Process. Technol., 77, 409 (2002).

5) S. Shimooka, M. Yamazaki, T. Takewaki, E. Akashige, F. Ikehata, H. Kakiuchi, M. Kubota and H. Matsuda, Proceedings of Int. Symposium on Eco Topia Science (2007).

6) N. Enteria, H. Yoshino, A. Mochida, A. Satake, R. Yoshie, R. Takaki, H. Yonekura, T. Mitamura and Y. Tanaka, Sol. Energy, 86, 1261 (2012).

7) C. X. Jia, Y. J. Dai, J. Y. Wu and R. Z. Wang, Energy Convers. Manag., 47, 2523 (2006).

8) C. X. Jia, Y. J. Dai, J. Y. Wu and R. Z. Wang, Int. J. Refrig., 30, 345 (2007).

9) J. Khedari, R. Rawangkul, W. Chimchavee, J. Hirunlabh and A. Watanasungsuit, Renew. Energy, 28, 1617 (2003).

10) J. Miyawaki, T. Kanda and K. Kaneko, Langmuir, 17, 664 (2001).

11) M. Sultan, T. Miyazaki, S. Koyama and B. B. Saha, Int. J. Environ., 4, 1 (2014).

12) I. I. El-Sharkawy, K. Uddin, T. Miyazaki, B. B. Saha, S. Koyama, J. Miyawaki and S.H. Yoon, Int. J. Heat Mass Transf., 73, 445 (2014).

13) I. I. El-Sharkawy, B. B. Saha, S. Koyama and K. C. Ng, Int. J. Heat Mass Transf., 49, 3104 (2006).

14) K. C. Ng, H. T. Chua, C. Y. Chung, C. H. Loke, T. Kashiwagi, A. Akisawa and B. B. Saha, Appl. Therm. 
Eng., 21, 1631 (2001).

15) C. L. McCallum, T. J. Bandosz, S. C. McGrother, E. A. Müller and K. E. Gubbins, Langmuir, 15, 533 (1999).

16) S. Brunauer, P. H. Emmett and E. Teller, J. Am. Chem. Soc., 60, 309 (1938).

17) C. Feng, H. Janssen, C. Wu, Y. Feng and Q. Meng, Build. Environ., 69, 64 (2013).

18) C. R. Oswin, J. Soc. Chem. Ind., 65, 419 (1946).

19) T. Miyazaki, A. Akisawa, B. B. Saha, I. I. El-Sharkawy and A. Chakraborty, Int. J. Refrig., 32, 846 (2009).

20) I. I. El-Sharkawy, K. Kuwahara, B. B. Saha, S. Koyama and K. C. Ng, Appl. Therm. Eng., 26, 859 (2006).

21) İ. Solmuş, C. Yamalı, B. Kaftanoğlu, D. Baker, and A. Çağlar, Appl. Energy, 87, 2062 (2010). 